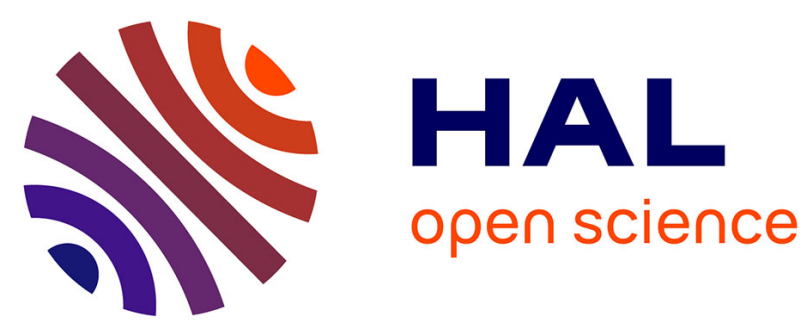

\title{
MRI-based experimentations of fingertip flat compression: Geometrical measurements and finite element inverse simulations to investigate material property parameters
}

Jérémy Dallard, Xavier Merlhiot, Noémie Petitjean, Sonia Duprey

\section{To cite this version:}

Jérémy Dallard, Xavier Merlhiot, Noémie Petitjean, Sonia Duprey. MRI-based experimentations of fingertip flat compression: Geometrical measurements and finite element inverse simulations to investigate material property parameters. Journal of Biomechanics, 2018, 67, pp.166-171. 10.1016/j.jbiomech.2017.11.024 . hal-01801874

\section{HAL Id: hal-01801874 \\ https://hal.science/hal-01801874}

Submitted on 28 May 2018

HAL is a multi-disciplinary open access archive for the deposit and dissemination of scientific research documents, whether they are published or not. The documents may come from teaching and research institutions in France or abroad, or from public or private research centers.
L'archive ouverte pluridisciplinaire HAL, est destinée au dépôt et à la diffusion de documents scientifiques de niveau recherche, publiés ou non, émanant des établissements d'enseignement et de recherche français ou étrangers, des laboratoires publics ou privés. 


\section{Accepted Manuscript}

Short communication

MRI-based experimentations of fingertip flat compression: geometrical measurements and finite element inverse simulations to investigate material property parameters

Jérémy Dallard, Xavier Merlhiot, Noémie Petitjean, Sonia Duprey

PII: S0021-9290(17)30679-6

DOI: https://doi.org/10.1016/j.jbiomech.2017.11.024

Reference: $\quad$ BM 8472

To appear in: $\quad$ Journal of Biomechanics

Accepted Date: $\quad 23$ November 2017

Please cite this article as: J. Dallard, X. Merlhiot, N. Petitjean, S. Duprey, MRI-based experimentations of fingertip flat compression: geometrical measurements and finite element inverse simulations to investigate material property parameters, Journal of Biomechanics (2017), doi: https://doi.org/10.1016/j.jbiomech.2017.11.024

This is a PDF file of an unedited manuscript that has been accepted for publication. As a service to our customers we are providing this early version of the manuscript. The manuscript will undergo copyediting, typesetting, and review of the resulting proof before it is published in its final form. Please note that during the production process errors may be discovered which could affect the content, and all legal disclaimers that apply to the journal pertain. 
MRI-based experimentations of fingertip flat compression: geometrical measurements and finite element inverse simulations to investigate material property parameters Jérémy Dallard $^{\mathrm{a}, \mathrm{b}}$, Xavier Merlhiot ${ }^{\mathrm{b}}$, Noémie Petitjean ${ }^{\mathrm{a}}$, Sonia Duprey ${ }^{\mathrm{a}, *}$

${ }^{a}$ Univ Lyon, Université Claude Bernard Lyon 1, IFSTTAR, LBMC UMR_T9406, F69622, Lyon, France

${ }^{\mathrm{b}}$ CEA, LIST, Interactive Simulation Laboratory, Gif-sur-Yvette, F-91191, France

*Corresponding author:

Sonia DUPREY

Laboratoire de Biomécanique et Mécanique des Chocs (LBMC)

IFSTTAR, Cité des Mobilités

25 Av F Mitterrand

69675 BRON Cedex

FRANCE

Phone: +33 (0)4 78656882

Email : sonia.duprey@univ-lyon1.fr

Short Communication - Word Count : 2076 words 


\section{Abstract}

Modeling human-object interactions is a necessary step in the ergonomic assessment of products. Fingertip finite element models can help investigating these interactions, if they are built based on realistic geometrical data and material properties. The aim of this study was to investigate the fingertip geometry and its mechanical response under compression, and to identify the parameters of a hyperelastic material property associated to the fingertip soft tissues.

Fingertip compression tests in an MRI device were performed on 5 subjects at either 2 or $4 \mathrm{~N}$ and at $15^{\circ}$ or $50^{\circ}$. The MRI images allowed to document both the internal and external fingertip dimensions and to build 5 subject-specific finite element models. Simulations reproducing the fingertip compression tests were run to obtain the material property parameters of the soft tissues.

Results indicated that two ellipses in the sagittal and longitudinal plane could describe the external fingertip geometry. The internal geometries indicated an averaged maximal thickness of soft tissues of $6.4 \pm 0.8 \mathrm{~mm}$ and a $4 \pm 1 \mathrm{~mm}$ height for the phalanx bone. The averaged deflections under loading went from $1.8 \pm 0.3 \mathrm{~mm}$ at $2 \mathrm{~N}, 50^{\circ}$ to $3.1 \pm 0.2 \mathrm{~mm}$ at $4 \mathrm{~N}, 15^{\circ}$. Finally, the following set of parameters for a second order hyperelastic law to model the fingertip soft tissues was proposed: $\mathrm{C}_{01}=0.59 \pm 0.09 \mathrm{kPa}$ and $\mathrm{C}_{20}=2.65 \pm 0.88 \mathrm{kPa}$.

These data should facilitate further efforts on fingertip finite element modeling.

Keywords: Fingertip; Pulp; Soft tissues; Experimental Compressions; MRI; Finite element; Hyperelasticity 


\section{Introduction}

Finite element (FE) fingertip models can help investigate fingertip-object interactions during manipulation tasks (Wu et al., 2006; Chamoret et al., 2016; Harih and Dolšak, 2014). This way, they can be helpful to predict the ergonomy of a product as in textile industries (Ciesielska-Wrobel et al., 2014) or haptic device conception (Ambrosi et al., 1999). However, FE models require both appropriate material properties and geometrical data to predict a biofidelic mechanical behavior (Harih and Tada, 2015; Harih et al., 2016).

The boundary conditions of dexterous manipulations correspond to compressions up to $10 \mathrm{~N}$, with various loading angles (Gonzalez et al., 2014; Daams, 1994). Prior experiments (Table 1) were carried out with loadings from 1 to 6N (Serina et al., 1997; Pawluk and Howe, 1999; Shimawaki and Sakai, 2007; Pérez-González et al., 2013 ) or with a prescribed $2 \mathrm{~mm}$-deflection (Srinivasan, 1989; Wu et al., 2003). Two studies also included up to 5N shear loads (Nakazawa et al., 2000; Pataky et al., 2005). Most of these studies consisted in compression tests with a flat loading plane tilted from $0^{\circ}$ to $90^{\circ}$, while a few experiments used a lineic (Srinivasan, 1989) or an indentation device (Pérez-González et al., 2013). These experiments include both static (Srinivasan, 1989; Serina et al., 1997; Shimawaki and Sakai, 2007; Pérez-González et al., 2013) and dynamic studies (Wu et al., 2003; Nakazawa et al., 2000; Pataky et al., 2005; Pawluk and Howe, 1999). However, these prior set of experimental data didn't allow to generate any subject-specific models. Hence, it prevents the identification of a material property and its parameters to model the fingertip soft tissues through an inverse method (i.e. optimizing the parameters of a numerical model until its simulated response fit the experimental one).

While fingertip external dimensions have been significantly documented based on large sample of populations (Greiner, 1991; Wu et al., 2003; Imrhan et al., 2006; Mandahawi et al., 2008; Cakit et al., 2014; Shimawaki and Sakai, 2007; Yoshida et al., 2006; Wang et al., 2012), its internal dimensions were only documented based on a few subjects (Serina et al., 1997; Harih and Tada, 2015). This lack of a large database of internal geometry dimensions compromises the right positioning of the bony phalanx into the fingertip pulp during the development of fingertip models that are not based medical images.

Thus, to facilitate further FE fingertip modeling, there is still a need for a thorough experimental data set that could be used to determine the parameters of a material property associated to the fingertip soft tissues and that would enlarge the existing set of internal geometry data. Hence, the objectives of this paper are to investigate the external and internal geometries of fingertips as well as their mechanical responses under compression and to identify material property parameters of the fingertip soft tissues. 


\section{Methods}

\subsection{Subjects}

Five healthy male subjects participated in this study (height: $1.75 \pm 0.036 \mathrm{~m}$, age: $32 \pm 8$ years; weight: $67.5 \pm 6 \mathrm{~kg}$ ). The rationale for recruiting only male subjects in this MRI-campaign was to avoid any pregnancy risks. The subjects gave informed consent prior to the experiments. Ethics approval was granted by the French Committee for Person Protection (CPP).

\subsection{Experimental protocol}

Images of the index finger of each subject were obtained using a 3T MRI scanner, (Magnetom Prisma, Siemens HealthCare, Erlangen, Germany). Isotropic 330 $\mu$ m-voxels were generated through a T1 sequence.

Then, fingers were loaded by an experimental device enabling to apply flat compression (Figure1a-b). The index was maintained, its dorsal part lying on an orientable plane. Medical images of the loaded fingers (250*250*100 $\mathrm{\mu mm}^{3}$ anisotropic voxels) were obtained through a T1 sequence.

Four different configurations were tested for each subject: $2 \mathrm{~N}$ and $4 \mathrm{~N}$ flat compressions at $15^{\circ}$ and $50^{\circ}($ Figure1c)

\subsection{Geometrical measurements}

For each MRI acquisition, manual segmentations were performed (www.slicer.org (Fedorov et al., 2012)) to differentiate the soft tissues (skin and adipose) and the bony phalanx. For each configuration, several points of the dorsal support and loading plane were identified and used in least-square optimisations to obtain their plane equation.

Geometrical dimensions of the unloaded index fingers were measured (Figure 2) on the images: $\mathrm{w}_{0}$ and $\mathrm{h}_{0}$, fingertip width and height; $\mathrm{w}_{\mathrm{p}}$ and $\mathrm{h}_{\mathrm{p}}$, phalanx width and height; $\mathrm{D}_{\mathrm{N} 0}, \mathrm{D}_{\mathrm{N} 45}, \mathrm{D}_{\mathrm{N} 90}$, thickness of the soft tissues at $0^{\circ}, 45^{\circ}$ and $90^{\circ}$. Two conics describing the curvatures in the sagittal and longitudinal planes were identified using a least-square optimisation (i.e. each conics section -parabola, ellipse and hyperbola- were tested to identify the best fit).

The deflection was calculated as the normal distance between the first contact point of the unloaded and final position of the loading plan. Estimations of the length and width of the contact area were calculated as the distances between the most extreme contacts point along the finger longitudinal and transversal axis. 


\subsection{FE inverse method}

Using the segmentation of the MRI images, subject-specific geometries were 3D-reconstructed for each subject. They were then meshed with tetrahedron elements $(1 \mathrm{~mm}$-characteristic length, as suggested (Petitjean et al., 2016)). The fingertip soft tissues are known to be heterogeneous (Clark., 2003; Hauck et al., 2004) with the skin itself consisting in multi-layers and the subcutaneous part being made of adipose tissue. However, to avoid a too complex model (i.e. having too many material property and geometrical parameters), an homogeneous representation of the fingertip soft tissues was chosen in accordance with several studies (Chamoret et al., 2013; Shimawaki and Sakai, 2007; Wu et al., 2002).

The material properties derived from the literature. The bony phalanx was considered as a rigid body (Srinivasan and Dandekar, 1996), and the nail was associated to a linear elastic material $(\mathrm{E}=170 \mathrm{MPa}, v=0.30)$ (Shimawaki and Sakai, 2007; Wu et al., 2004; Wu et al., 2002). The material properties of the homogeneous soft tissues were set as nearly-incompressible hyperelastic (Dandekar et al., 2003; Shao et al., 2010; Yin et al., 2010). A second order law is necessary to reproduce the strain-hardening effect at large strains (Gent., 2012; Horgan and Saccomandi, 2002; Horgan and Saccomandi, 2003). Thus, a second order hyperelastic law was chosen (Equation 1), to avoid having too many parameters to identify as imposed by higher order laws:

, with a 0.49 Poisson ratio (Dandekar et al., 2003; Shao et al., 2010; Yin et al., 2010). A second order law is necessary to reproduce the strain-hardening effect at large strains (Gent., 2012; Horgan and Saccomandi, 2002; Horgan and Saccomandi, 2003). Thus, a second order hyperelastic law was chosen (Equation 1), to avoid having too many parameters to identify as imposed by higher order laws:

$$
W=C_{01}\left(I_{2}-3\right)+C_{20}\left(I_{1}-3\right)^{2}+F_{v o l}(K(v), J)
$$

where $K$ is the bulk modulus linked to the Poisson coefficient, $K=2 G(1+v) / 3(1-2 v)$ with $G=0.5\left(C_{10}+C_{01}\right)$; and $\mathbf{J}$ the Jacobian linked to the third invariant: $\mathrm{I}_{3}=(\operatorname{detF})^{2}=\mathrm{J}^{2}$.

Simulations were run with a FE implicit code LS-Dyna (LSTC, Livermore, USA). The boundary conditions included a fixed bony phalanx and a quasi-static displacement of the loading plane $(1 \mathrm{~mm} / \mathrm{s})$. Inverse methods were performed to obtain the material property parameters: $C_{01}$ and $C_{20}$ were varied until both the simulated deflections at 2 and $4 \mathrm{~N}$ under $15^{\circ}$-flat compressions were within $0.1 \mathrm{~mm}$ of the experimental results.

\section{Results}

\subsection{Geometrical measurements}

The averaged fingertip width and height were $16.7 \pm 1.1 \mathrm{~mm}$ and $12.0 \pm 0.8 \mathrm{~mm}$, while the averaged 
width and height of the bony phalanx were $4.0 \pm 0.8 \mathrm{~mm}$ and $7.1 \pm 0.7 \mathrm{~mm}$. The thickness of soft tissues was maximal at $0^{\circ}$ with $6.4 \pm 0.8 \mathrm{~mm}$ (Table 2). Furthermore, the conics describing the best the frontal and sagittal curvatures were ellipses for the 5 subjects. The anthropometric measurements didn't show large standard variations (Table 2). The dimensions of the voxels generated a measurement uncertainty of $\pm 0.33 \mathrm{~mm}$.

Regarding soft tissue deflections, larger deflections were measured at $15^{\circ}$ than at $50^{\circ}$ (Figure 3 , Table 3). The standard deviations were up to $0.34 \mathrm{~mm}$ and the uncertainty was $\pm 0.58 \mathrm{~mm}$ due to the voxel sizes $(0.33+0.25=0.58 \mathrm{~mm})$

Regarding the dimensions of the contact area (Figure 3, Table 3), the width wasn't much influenced by the compression load nor the angle. The length of the contact area wasn't influenced by the compression load, but by the angle: it was about twice larger at $15^{\circ}$ than at $50^{\circ}$.

\subsection{FE inverse method}

The inverse methods provided averaged errors (between the simulated and experimental deflections) of $0.07 \mathrm{~mm}$. The resulting averaged parameters were: $\mathrm{C}_{01}=0.59 \pm 0.09 \mathrm{kPa}$ and $\mathrm{C}_{20}=2.65 \pm 0.88 \mathrm{kPa}$ (Table 4).

\section{Discussion}

The objectives of the present study were to provide external and internal geometries of fingertips and to investigate their mechanical responses under compression to identify material property parameters of the fingertip soft tissues.

Regarding the geometry, experimental studies from the literature mainly documented the external fingertip dimensions. The external geometry results are in accordance with the anthropometry measurements by Serina et al., (1997) but not with those from Greiner (1991). This can be explained by the fact that this last study focused on a specific population of soldiers. The small standard deviations of the current fingertip dimensions could be explained by the fact that the subjects had similar stature (close to $1.75 \mathrm{~m}$ ). However, this point should be confirmed by expanding the study to a larger sample. A few numerical studies built fingertip models based on ellipses (Shao et al., 2010; Harih and Dolšak, 2014) or ellipsoids (Wagner et al., 2008; Yin et al., 2010) as for external geometry. The present results seem to confirm that ellipses could be appropriate; even though this conclusion will need further investigations on more subjects to be confirmed. As for the internal geometry, the present results in terms of soft tissue thickness at $0^{\circ}(6.4 \pm 0.81 \mathrm{~mm})$ are comparable to the experimental results provided by Serina et al. (1997) $\left(5.9 \mathrm{~mm}\right.$ at $\left.0^{\circ}\right)$. 
Regarding the deflection and contact area of the fingertips under loading compression, the present results are in accordance with prior ones (Serina et al., 1997; Shimawaki and Sakai, 2007) that were obtained under similar experimental conditions but using different measurement methods. Indeed, the averaged deflection determined at $4 \mathrm{~N}, 50^{\circ}(2.12 \mathrm{~mm})$ is consistent with the experimental data from Serina et al. (1997) who reported an averaged $4 \mathrm{~N}$-deflection of $2.24 \mathrm{~mm}$ at $45^{\circ}$. Furthermore, the length and width of the contact areas measured (Table 3) are consistent with the experimental data measured by Shimawaki and Sakai (2007) who obtained, at $15^{\circ}$, for $4 \mathrm{~N}$-compressions, a length of $21.5 \mathrm{~mm}$ and a width of $13.2 \mathrm{~mm}$ at the contact area. This accordance confirms the relevance of our measurement approach based on the analysis of medical images despite its uncertainty associated to the images resolution. It was observed that the larger the loading angle is, the stiffer is the fingertip and the smaller is the area of contact. This can be explained by the decreasing amount of soft tissue to be compressed with higher angles. These results confirm that the influence of the soft tissue thickness is paramount in the fingertip response to loading and that rightly positioning the bony phalanx inside the whole fingertip is essential in FE fingertip modeling.

As for the material property, the parameters were predicted through an inverse method with a mean error of $0.07 \mathrm{~mm}$. This low error confirms that the second order hyperelastic law used here can thoroughly suit fingertip models dedicated to plane compression involving boundary conditions close to a [2 N; $4 \mathrm{~N}]$ loading range and $\mathrm{a}\left[15^{\circ} ; 50^{\circ}\right]$ angle range. The parameters predicted in this study will have to be used with care, since they will only suit models the above-mentioned loadings, and will only suit models whose anthropometries are close to the present subjects.

The main limitation of this study is the large results' uncertainty due to the MRI images resolution. As a perspective, a 7 T-MRI device could be used to further investigate the fingertip. As already mentioned, the small number of tested subjects, which were all male, is also a limitation. A larger sample of subjects integrating female subjects, would generate a higher variability in fingertip dimensions and would allow to confirm the present preliminary conclusions. A last limitation is the low number of loading configurations compared to the number of loading possibilities in dexterous manipulation. Since the experimental device can apply shear forces, further studies will include shear configuration and compression at various angles and loads. This would permit to obtain material property parameters that would fit a larger range of boundary conditions.

Finally, a numerical sensitivity analysis could interestingly reveal the influence of each parameter of the FE fingertip model (i.e. either geometrical parameters or material property parameters) on the different results and could allow identify where the experimental efforts should be directed to. 


\section{Acknowledgements}

Jéremy Dallard received a grant from CEA-List for this work. The authors would like to warmly thank the CERMEP team for its support in the experiments organization and MRI acquisition, Danièle Ibarola, Franck Lamberton and Jamila Lagha. The authors also want to thank the doctor Georges Baraton for his help in the conduct of the experimental campaign and his spirited advices.

\section{Conflict of interest statement}

The authors hereby affirm that the study does not raise any conflict of interest. 


\section{References}

Ambrosi, G., Bicchi, A., De Rossi, D., \& Scilingo, E. P., 1999. The role of contact area spread rate in haptic discrimination of softness. In Robotics and Automation, 1999. Proceedings. 1999 IEEE International Conference, 1, 305-310.

Ciesielska-Wrobel, I., Van Langenhove, L., \& Grabowska, K. (2014). Fingertip skin models for analysis of the haptic perception of textiles. Journal of Biomedical Science and Engineering, 7, 1-6.

Cakit, E., Durgun, B., Cetik, O., Yoldas, O., 2014. A Survey of Hand Anthropometry and Biomechanical Measurements of Dentistry Students in Turkey. Hum. Factors Man. 24, 739-753. https://doi.org/10.1002/hfm.20401

Chamoret, D., Bodo, M., Roth, S., 2016. A first step in finite-element simulation of a grasping task. Computer Assisted Surgery 0, 1-8. https://doi.org/10.1080/24699322.2016.1240294

Clark, D. C. (2003). Common acute hand infections. American family physician, 68(11), 2167-2176.

Daams, B., 1994. Human force exertion in user-product interaction: backgrounds for design, TU Delft, Delft University of Technology. ed. Delft, The Netherlands.

Dandekar, K., Raju, B.I., Srinivasan, M.A., 2003. 3-D Finite-Element Models of Human and Monkey Fingertips to Investigate the Mechanics of Tactile Sense. J Biomech Eng 125, 682-691. https://doi.org/10.1115/1.1613673

Fedorov, A., Beichel, R., Kalpathy-Cramer, J., Finet, J., Fillion-Robin, J.-C., Pujol, S., Bauer, C., Jennings, D., Fennessy, F., Sonka, M., Buatti, J., Aylward, S., Miller, J.V., Pieper, S., Kikinis, R., 2012. 3D Slicer as an image computing platform for the Quantitative Imaging Network. Magnetic Resonance Imaging, Quantitative Imaging in Cancer 30, 1323-1341. https://doi.org/10.1016/j.mri.2012.05.001

Gent, A. N. (2012). Engineering with rubber: how to design rubber components. Carl Hanser Verlag GmbH Co KG.

Gonzalez, F., Gosselin, F., Bachta, W., 2014. Analysis of Hand Contact Areas and Interaction Capabilities During Manipulation and Exploration. IEEE Transactions on Haptics 7, 415-429. https://doi.org/10.1109/TOH.2014.2321395

Greiner, T., 1991. Hand anthropometry of US army personnel (No. No. TR-92/011). Army Natick Research Development and Engineering Center., MA, USA.

Harih, G., Dolšak, B., 2014. Recommendations for tool-handle material choice based on finite element analysis. Applied Ergonomics 45, 577-585. https://doi.org/10.1016/j.apergo.2013.07.014

Harih, G., M. Tada, and B. Dolšak, Justification for a 2D versus 3D fingertip finite element model during static contact simulations. Computer Methods in Biomechanics and Biomedical Engineering 2016. 19(13): p. $1409-1417$

Harih, G., Tada, M., 2015. Finite element evaluation of the effect of fingertip geometry on contact pressure during flat contact. Int. J. Numer. Meth. Biomed. Engng. 31, n/a-n/a. https://doi.org/10.1002/cnm.2712

Hauck, R. M., Camp, L., Ehrlich, H. P., Saggers, G. C., Banducci, D. R., \& Graham, W. P. (2004). Pulp nonfiction: microscopic anatomy of the digital pulp space. Plastic and reconstructive surgery, 113(2), 536-539.

Horgan, C.O., Saccomandi, G., 2003. A description of arterial wall mechanics using limiting chain extensibility constitutive models. Biomechan Model Mechanobiol 1, 251-266. https://doi.org/10.1007/s10237-0020022-z

Horgan, C.O., Saccomandi, G., 2002. Constitutive Modelling of Rubber-Like and Biological Materials with Limiting Chain Extensibility. Mathematics and Mechanics of Solids 7, 353-371. https://doi.org/10.1177/108128028477

Imrhan, S.N., Sarder, M.D., Mandahawi, N., 2006. Hand Anthropometry in a Sample of Bangladesh Males. IIE Annual Conference. Proceedings 1-5.

Mandahawi, N., Imrhan, S., Al-Shobaki, S., Sarder, B., 2008. Hand anthropometry survey for the Jordanian population. International Journal of Industrial Ergonomics 38, 966-976. https://doi.org/10.1016/j.ergon.2008.01.010

Nakazawa, N., Ikeura, R., Inooka, H., 2000. Characteristics of human fingertips in the shearing direction. Biol Cybern 82, 207-214. https://doi.org/10.1007/s004220050020

Pataky, T.C., Latash, M.L., Zatsiorsky, V.M., 2005. Viscoelastic response of the finger pad to incremental tangential displacements. Journal of Biomechanics 38, 1441-1449. https://doi.org/10.1016/j.jbiomech.2004.07.004

Pawluk, D.T.V., Howe, R.D., 1999. Dynamic Contact of the Human Fingerpad Against a Flat Surface. J Biomech Eng 121, 605-611. https://doi.org/10.1115/1.2800860

Pérez-González, A., Vergara, M., Sancho-Bru, J.L., 2013. Stiffness map of the grasping contact areas of the human hand. Journal of Biomechanics 46, 2644-2650. https://doi.org/10.1016/j.jbiomech.2013.08.005

Petitjean, N., Dallard, J., Merlhiot, X., Duprey, S., 2016. Human fingertip finite element models: towards a set of parameters for a hyperelastic law. Presented at the 22nd Congress of the European Society of 
Biomechanics, Lyon, France.

Serina, E.R., Mote, C.D., Rempel, D., 1997. Force response of the fingertip pulp to repeated compressionEffects of loading rate, loading angle and anthropometry. Journal of Biomechanics 30, 1035-1040. https://doi.org/10.1016/S0021-9290(97)00065-1

Shao, F., Childs, T.H.C., Barnes, C.J., Henson, B., 2010. Finite element simulations of static and sliding contact between a human fingertip and textured surfaces. Tribology International 43, 2308-2316. https://doi.org/10.1016/j.triboint.2010.08.003

Shimawaki, S., Sakai, N., 2007. Quasi-static Deformation Analysis of a Human Finger using a Threedimensional Finite Element Model Constructed from CT Images. Journal of Environment and Engineering 2, 56-63. https://doi.org/10.1299/jee.2.56

Srinivasan, M.A., 1989. Surface deflection of primate fingertip under line load. Journal of Biomechanics 22 , 343-349. https://doi.org/10.1016/0021-9290(89)90048-1

Srinivasan, M.A., Dandekar, K., 1996. An Investigation of the Mechanics of Tactile Sense Using TwoDimensional Models of the Primate Fingertip. J Biomech Eng 118, 48-55. https://doi.org/10.1115/1.2795945

Wagner, M.B., Gerling, M.B.E.G.J., Scanlon, J., 2008. Validation of a 3-D Finite Element Human Fingerpad Model Composed of Anatomically Accurate Tissue Layers, in: 2008 Symposium on Haptic Interfaces for Virtual Environment and Teleoperator Systems. Presented at the 2008 Symposium on Haptic Interfaces for Virtual Environment and Teleoperator Systems, pp. 101-105. https://doi.org/10.1109/HAPTICS.2008.4479922

Wang, Z., Wang, L., Ho, V.A., Morikawa, S., Hirai, S., 2012. A 3-D Nonhomogeneous FE Model of Human Fingertip Based on MRI Measurements. IEEE Transactions on Instrumentation and Measurement 61, 3147-3157. https://doi.org/10.1109/TIM.2012.2205102

Wu, J.Z., Dong, R.G., Rakheja, S., Schopper, A.W., 2002. Simulation of mechanical responses of fingertip to dynamic loading. Medical Engineering \& Physics 24, 253-264. https://doi.org/10.1016/S13504533(02)00018-8

Wu, J.Z., Dong, R.G., Rakheja, S., Schopper, A.W., Smutz, W.P., 2004. A structural fingertip model for simulating of the biomechanics of tactile sensation. Medical Engineering \& Physics 26, 165-175. https://doi.org/10.1016/j.medengphy.2003.09.004

Wu, J.Z., Dong, R.G., Smutz, W.P., Rakheja, S., 2003. Dynamic interaction between a fingerpad and a flat surface: experiments and analysis. Medical Engineering \& Physics 25, 397-406. https://doi.org/10.1016/S1350-4533(03)00035-3

Wu, J.Z., Welcome, D.E., Dong, R.G., 2006. Three-dimensional finite element simulations of the mechanical response of the fingertip to static and dynamic compressions. Computer Methods in Biomechanics and Biomedical Engineering 9, 55-63. https://doi.org/10.1080/10255840600603641

Yin, J., Gerling, G.J., Chen, X., 2010. Mechanical modeling of a wrinkled fingertip immersed in water. Acta Biomaterialia 6, 1487-1496. https://doi.org/10.1016/j.actbio.2009.10.025

Yoshida, H., Tada, M., Mochimaru, M., 2006. 3d finite element analysis of the frictional behavior of the human fingertip. Presented at the Engineering in Medicine and Biology Society. 28th Annual International Conference of the IEEE, pp. 91-94. 


\section{Captions of the Figures}

Figure 1: Illustrations of the experimental set-up. a) A subject is lying in the MRI tunnel, his arm and hand maintained by sand bags and his finger loaded. b) The specific device enabling to load the finger using sand bags of $2 \mathrm{~N}$ or $4 \mathrm{~N}$. c) Two different wedges $\left(15^{\circ}\right.$ or $\left.50^{\circ}\right)$ are used to generate different flat compressions.

Figure 2: Transversal and longitudinal section of the conics model of the fingertip

Figure 3: a) Force vs deflection at $2 \mathrm{~N}$ and $4 \mathrm{~N}$, at $15^{\circ}$ and $50^{\circ}$. b) Length of the fingertip contact areas at $2 \mathrm{~N}$ and $4 \mathrm{~N}, 15^{\circ}$ and $50^{\circ}$. c) Width of the fingertip contact areas at $2 \mathrm{~N}$ and $4 \mathrm{~N}, 15^{\circ}$ and $50^{\circ}$ 

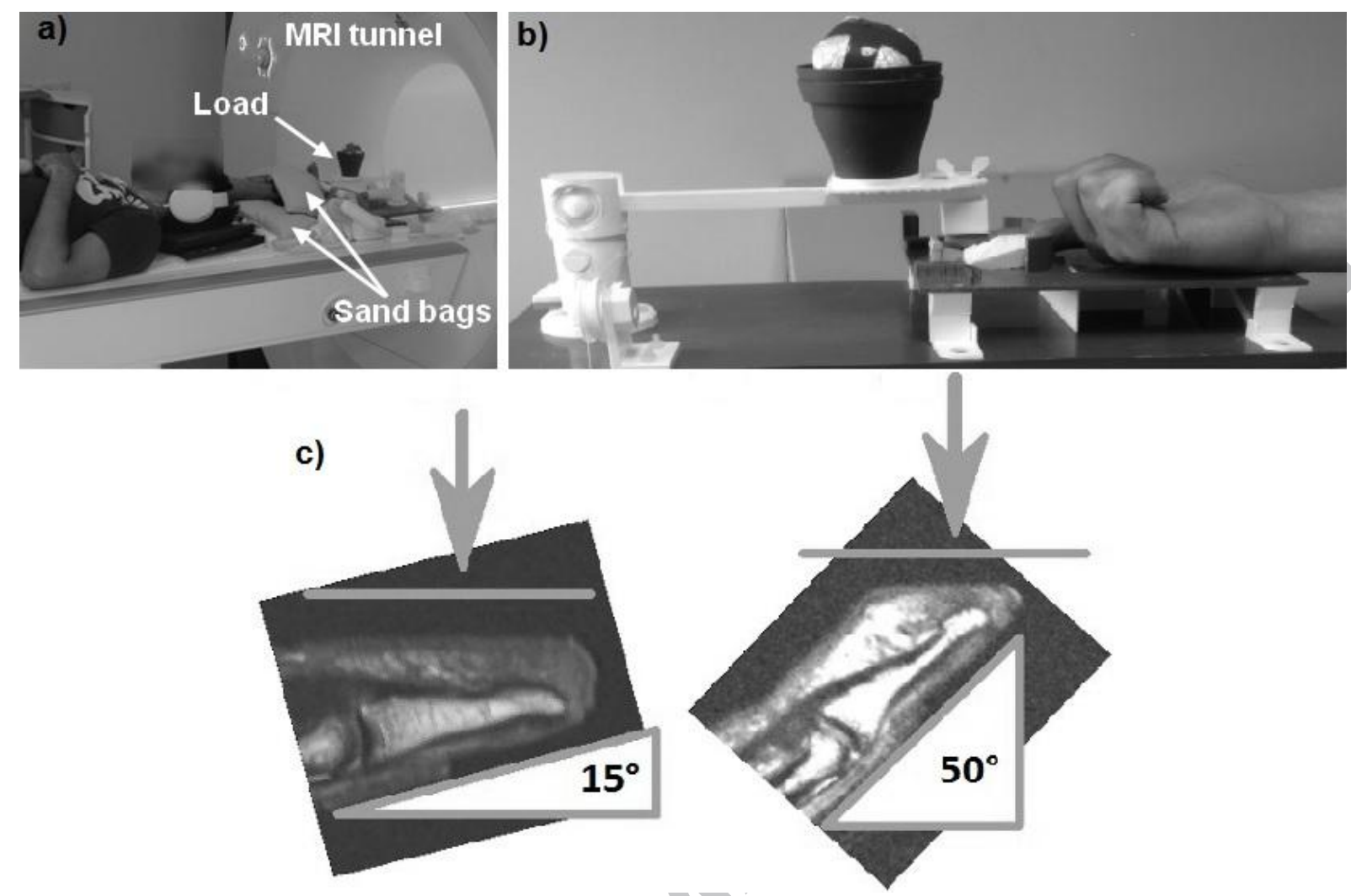

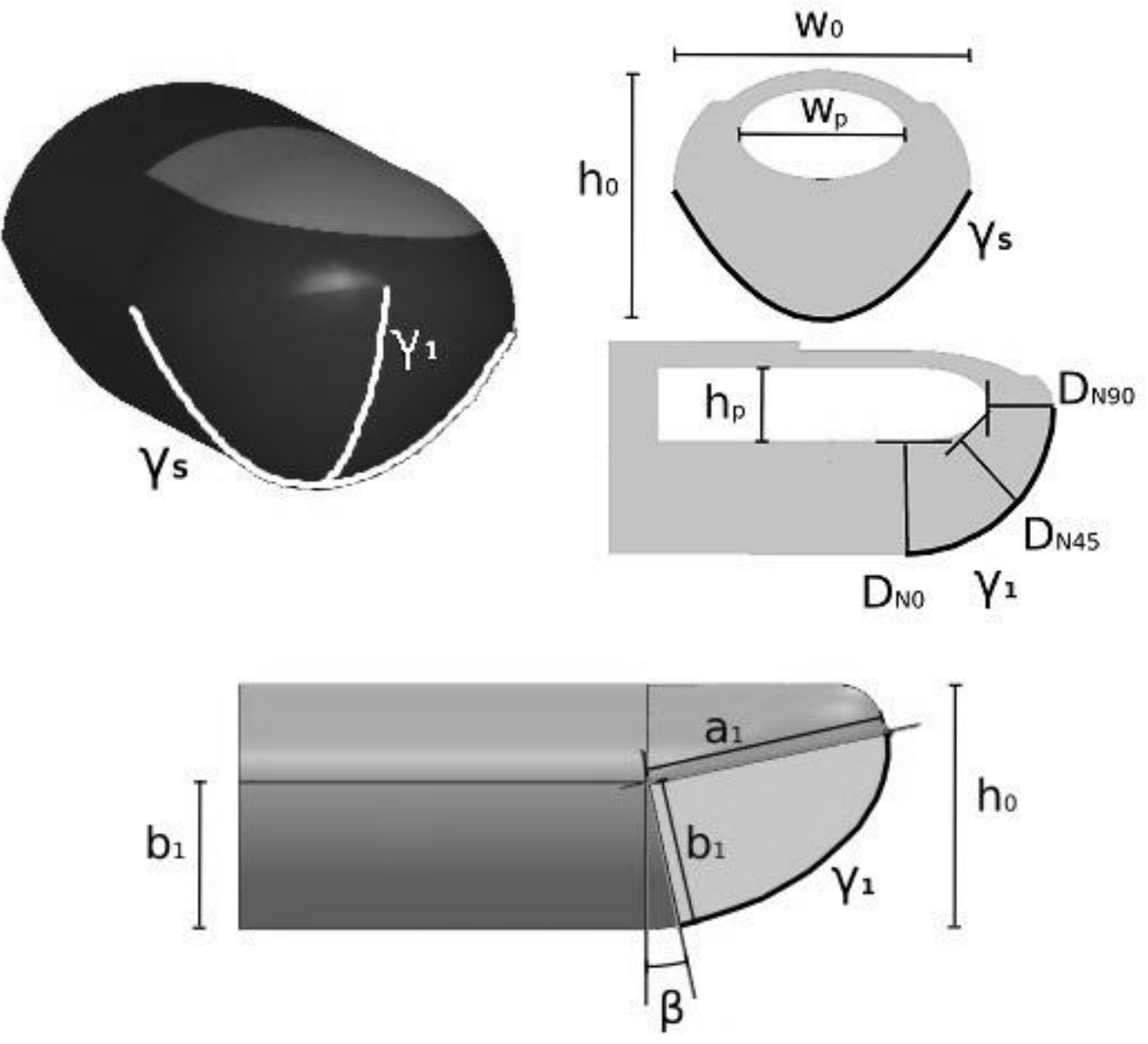


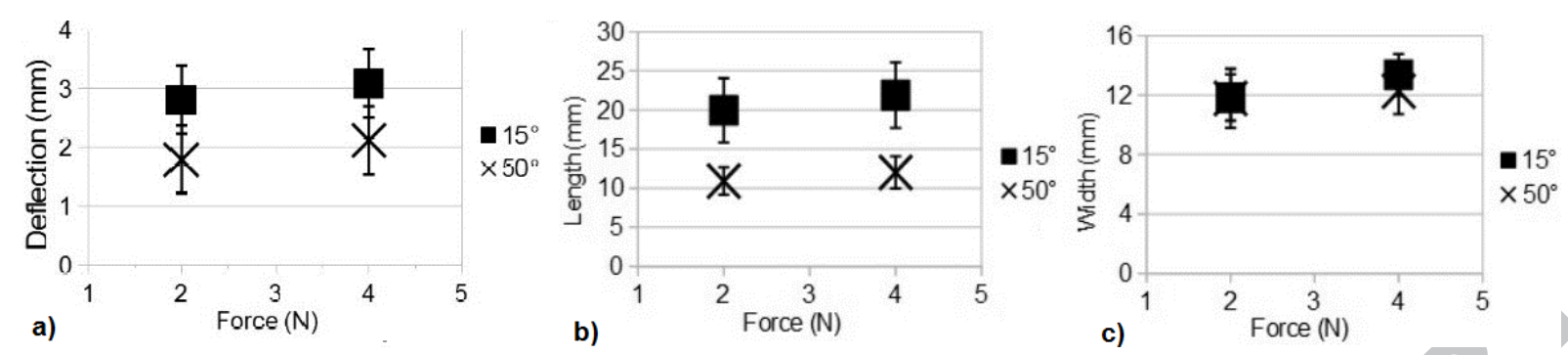


Table 1: Prior experimentations concerning fingertip mechanical characterization

\begin{tabular}{|c|c|c|c|c|c|c|}
\hline Study & $\begin{array}{c}\text { Contact } \\
\text { angle }\left(^{\circ}\right)\end{array}$ & $\begin{array}{l}\text { Subjects } \\
(\mathrm{M}=\text { male, } \\
\mathrm{F}=\text { female })\end{array}$ & $\begin{array}{l}\text { Loading type } \\
\text { (loading device) }\end{array}$ & Imposed condition & Results & $\begin{array}{l}\text { Geometrical } \\
\text { description }\end{array}$ \\
\hline $\begin{array}{l}\text { Srinivasan, } \\
1989\end{array}$ & 0 & $\begin{array}{l}4 \text { primates, } \\
3 \text { human } \\
\text { subjects }\end{array}$ & $\begin{array}{l}\text { Static compression } \\
\text { (Line loading) }\end{array}$ & $2 \mathrm{~mm}$ deflection & $\begin{array}{l}\text { External shape } \\
\text { deflection }\end{array}$ & \\
\hline $\begin{array}{c}\text { Serina et al., } \\
1997\end{array}$ & $0,45,90$ & $12 \mathrm{M}, 8 \mathrm{~F}$ & $\begin{array}{c}\text { Repeated static } \\
\text { compression (Flat } \\
\text { plane) }\end{array}$ & $1 \mathrm{~N} ; 4 \mathrm{~N}$ loading & $\begin{array}{c}\text { Force vs } \\
\text { Displacement }\end{array}$ & $\begin{array}{c}\text { Length, Width and } \\
\text { Height }\end{array}$ \\
\hline Wu et al., 2003 & 20 & $2 \mathrm{M}, 2 \mathrm{~F}$ & $\begin{array}{c}\text { Dynamic } \\
\text { compression (Flat } \\
\text { plane) }\end{array}$ & $2 \mathrm{~mm}$ deflection & $\begin{array}{c}\text { Force vs } \\
\text { Displacement; Force } \\
\text { vs Time }\end{array}$ & Width and Height \\
\hline $\begin{array}{c}\text { Nakazawa et } \\
\text { al., } 2000\end{array}$ & 15 & $3 \mathrm{M}$ & $\begin{array}{c}\text { Dynamic shear } \\
\text { loading (Flat plane) }\end{array}$ & $\begin{array}{c}\text { Loading } \\
\text { Normal: up to } 4.1 \mathrm{~N} \\
\text { Shear: up to } 2 \mathrm{~N} \\
\end{array}$ & $\begin{array}{l}\text { Displacement vs } \\
\text { Time; Area of } \\
\text { contact vs Force }\end{array}$ & - \\
\hline $\begin{array}{c}\text { Pataky et al., } \\
2005\end{array}$ & 0 & $6 \mathrm{M}, 3 \mathrm{~F}$ & $\begin{array}{c}\text { Dynamic } \\
\text { compression (Flat } \\
\text { plane) }\end{array}$ & $\begin{array}{c}\text { Loading } \\
\text { Normal: up to } 5 \mathrm{~N} \\
\text { Shear: up to } 5 \mathrm{~N}\end{array}$ & $\begin{array}{c}\text { Force vs } \\
\text { Displacement }\end{array}$ & - \\
\hline $\begin{array}{l}\text { Pawluk and } \\
\text { Howe, } 1999\end{array}$ & {$[20 ; 40]$} & $4 \mathrm{M}, 1 \mathrm{~F}$ & $\begin{array}{c}\text { Dynamic } \\
\text { compression (Flat } \\
\text { plane) }\end{array}$ & $\begin{array}{l}\text { Loading up to } 3 \mathrm{~N} \\
\text { Velocity up to } \\
80 \mathrm{~mm} / \mathrm{s}\end{array}$ & $\begin{array}{c}\text { Force vs } \\
\text { Displacement; } \\
\text { Pressure vs } \\
\text { Displacement }\end{array}$ & - \\
\hline $\begin{array}{l}\text { Shimawaki and } \\
\text { Sakai, } 2007\end{array}$ & 15 & $17 \mathrm{M}$ & $\begin{array}{c}\text { Static compression } \\
\text { (Flat plane) }\end{array}$ & Loading up to $4.5 \mathrm{~N}$ & $\begin{array}{l}\text { Width and Length of } \\
\text { contact area vs Force }\end{array}$ & - \\
\hline $\begin{array}{l}\text { Pérez-González } \\
\text { et al., } 2013\end{array}$ & 0 & $10 \mathrm{M}, 10 \mathrm{~F}$ & $\begin{array}{l}\text { Static indentation } \\
(3,8 \mathrm{~mm} \text { diameter } \\
\text { cylinder })\end{array}$ & Loading up to $6 \mathrm{~N}$ & $\begin{array}{c}\text { Force vs } \\
\text { Displacement }\end{array}$ & - \\
\hline
\end{tabular}


Table 2: Fingertip anthropometric measurements. $\mathrm{w}_{0}$ and $\mathrm{h}_{0}$ are the mean width and height of the fingertip; $\mathrm{w}_{\mathrm{p}}$ and $h_{p}$ are the mean width and height of the bony phalanx; $D_{N 0}, D_{N 45}$ and $D_{N 90}$ are the fingertip soft tissue thicknesses measured at different angles; $\gamma_{1}\left(a_{1} ; b_{l}\right)$ and $\gamma_{S}\left(a_{S} ; b_{S}\right)$ are the longitudinal and frontal ellipses (first axis length; second axis length), their orientation is given by the $\beta$ angle.

\begin{tabular}{ccccccccccc} 
& $\mathbf{w}_{\mathbf{0}}$ & $\mathbf{h}_{\mathbf{0}}$ & $\mathbf{h}_{\mathbf{p}}$ & $\mathbf{w}_{\mathbf{p}}$ & $\mathbf{D}_{\mathrm{N} \mathbf{0}}$ & $\mathbf{D}_{\mathrm{N} 45}$ & $\mathbf{D}_{\mathrm{N} 90}$ & $\boldsymbol{\gamma}_{\mathbf{1}}\left(\mathbf{a}_{\mathbf{l}} ; \mathbf{b}_{\mathbf{1}}\right)$ & $\gamma_{\mathbf{S}}\left(\mathbf{a}_{\mathbf{s}} ; \mathbf{b}_{\mathbf{S}}\right)$ & $\boldsymbol{\beta}\left({ }^{\circ}\right)$ \\
\hline Subject 1 & 16 & 13 & 3.8 & 7.7 & 7.5 & 4.3 & 2.5 & $11.5 ; 7.2$ & $16 ; 7.2$ & 10.2 \\
Subject 2 & 16 & 12.5 & 5.6 & 7.9 & 5.41 & 3.52 & 2.9 & $12.1 ; 7.6$ & $16 ; 7.6$ & 19.5 \\
Subject 3 & 17 & 11 & 4 & 8.1 & 6.4 & 3.4 & 2.7 & $10.7 ; 6.7$ & $17 ; 6.7$ & 12.1 \\
Subject 4 & 16 & 11.5 & 2.7 & 6.3 & 6.7 & 2.8 & 1.9 & $11.6 ; 6$ & $16 ; 6$ & 12.1 \\
Subject 5 & 18.5 & 12 & 3.7 & 7.1 & 5.9 & 2.7 & 1.7 & $14.1 ; 6.5$ & $18.5 ; 6.5$ & 2.3 \\
\hline Mean (mm) & $\mathbf{1 6 . 7}$ & $\mathbf{1 2 . 0}$ & $\mathbf{4 . 0}$ & $\mathbf{7 . 4}$ & $\mathbf{6 . 4}$ & $\mathbf{3 . 3}$ & $\mathbf{2 . 3}$ & $\mathbf{1 2 ; 6 . 8}$ & $\mathbf{1 6 . 7} \mathbf{6 . 8}$ & $\mathbf{1 1 . 2}$ \\
StD (mm) & $\mathbf{1 . 1}$ & $\mathbf{0 . 8}$ & $\mathbf{1 . 0}$ & $\mathbf{0 . 7}$ & $\mathbf{0 . 8}$ & $\mathbf{0 . 6}$ & $\mathbf{0 . 5}$ & $\mathbf{1 . 3 ; 0 . 6}$ & $\mathbf{1 . 1 ; 0 . 4}$ & $\mathbf{6 . 1}$ \\
\hline
\end{tabular}


Table 3: Deflections and dimensions of the contact area averaged over the subjects at $2 \mathrm{~N}, 4 \mathrm{~N}, 15^{\circ}$ and $50^{\circ}$

\begin{tabular}{ccccccc} 
& \multicolumn{2}{c}{ Deflections $(\mathrm{mm})$} & \multicolumn{2}{c}{ Length of the contact area $(\mathrm{mm})$} & \multicolumn{2}{c}{ Width of the contact area (mm) } \\
\cline { 2 - 7 } & $2 \mathrm{~N}$ & $4 \mathrm{~N}$ & $2 \mathrm{~N}$ & $4 \mathrm{~N}$ & $2 \mathrm{~N}$ & $4 \mathrm{~N}$ \\
\hline $15^{\circ}$ & $2.8 \pm 0.2$ & $3.1 \pm 0.2$ & $20.0 \pm 4.1$ & $21.9 \pm 4.2$ & $11.8 \pm 1.6$ & $13.4 \pm 1.4$ \\
\hline $50^{\circ}$ & $1.8 \pm 0.3$ & $2.2 \pm 0.4$ & $10.9 \pm 1.8$ & $12.0 \pm 2.0$ & $11.8 \pm 2.0$ & $12.3 \pm 1.6$ \\
\hline
\end{tabular}

Table 4: Results of the $\mathrm{C}_{01}$ and $\mathrm{C}_{20}$ identification for each subject (units: $\mathrm{kPa}$ )

\begin{tabular}{ccc} 
& $\mathbf{C}_{\mathbf{0 1}}$ & $\mathbf{C}_{\mathbf{2 0}}$ \\
\cline { 2 - 3 } Subject 1 & 0.7 & 2.8 \\
Subject 2 & 0.6 & 1.95 \\
Subject 3 & 0.5 & 1.8 \\
Subject 4 & 0.65 & 4 \\
Subject 5 & 0.5 & 2.7 \\
\hline Mean & $\mathbf{0 . 5 9}$ & $\mathbf{2 . 6 5}$ \\
StD & $\mathbf{0 . 0 9}$ & $\mathbf{0 . 8 8}$ \\
\hline
\end{tabular}

